\title{
SAMENWERKING OP BIOLOGISCH GEBIED TUSSCHEN NEDERLAND EN INDIË
}

\author{
DOOR
}

\author{
Dr. J. C. KONINGSBERGER.
}

In deze. Feestuitgave mogen enkele bladzijden worden gewijd aan een onderwerp, dat steeds de bijzondere aandacht heeft genoten van hem, wien ze is opgedragen, aan een terrein, waarop hij zich met evenveel voorliefde als rijken uitslag heeft bewogen.

Voor wie geen vreemdeling is in de geschiedenis der veelzijdige betrekkingen, die in den loop der laatste eeuwen tusschen Nederland en Indië hebben bestaan, staat weinig minder vast dan het feit, dat de juiste samenwerking tusschen die twee, ver van elkander verwijderde deelen van het Hol landsche gebied dikwijls véél, niet zelden alles heeft te wenschen overgelaten. Twee groepen van oorzaken hebben daartoe medegewerkt. De eerste was gelegen in den grooten afstand en het is duidelijk, dat haar invloed geringer werd, naarmate die afstand in korter tijden werd overbrugd. De tweede werd geboden door de geestesgesteldheid van hen, die tot samenwerking waren geroepen, doch wier persoonlijke opvattingen hen daarom nog niet tot uitverkorenen maakten.

Het natuurwetenschappelijk onderzoek van Indië heeft van het een en het ander in ruime mate den ongunstigen invloed ondervonden en eerst in het laatste veertigtal jaren heeft het zich, onder geniale leiding en opwekkend vóórgaan, aan dien invloed weten te ontworstelen.

Aan die leiding een woord van waardeering en hulde te wijden en op het tweetal voorgangers, van wie zij uitging, het licht te doen vallen, is het doel dezer bladzijden.

Een korte terugblik in het verledene moge voorafgaan.

De geschiedenis van het natuurwetenschappelijk onderzoek van Nederlandsch Indië is rijk aan afwisselende perioden van verheffing en van depressie; tweemaal, in 1879 en in $1915^{1}$ ), heeft zij in algemeene trekken een beschrijving gevonden, die daarvan een duidelijk getuigenis aflegt.

In het lange tijdperk; dat aan het begin der negentiende eeuw voorafging, zien wij daarbij in hoofdzaak individueele pogingen in de goede richting in het werk gesteld. Nu eens met meer, soms zelfs met blijvend, maar dikwijls met minder en niet meer dan tijdelijk succes bekroond, vermochten zij toch alle tesamen nog niet den grondslag te leggen, waarop latere geslachten stelselmatig konden voortbouwen. Er werden bouwsteenen geleverd, soms van groote, zelfs van onschatbare waarde, maar die steenen bleven afzonderlijk liggen en veelal waren ze ook niet geschikt om tot één geheel, tot één fundament te worden bijeengevoegd.

Eerst in het begin der vorige eeuw kwam het inzicht tot bewustzijn en uiting, dat vóór alle dingen organisatie noodig was, dat er systeem moest worden gebracht in de verdere verrichtingen,

1) Beide zijn Academische Proefschriften van natuuronderzoekers, die door omstandigheden niet in de gelegenheid waren, een proefschrift van den gebruikelijken inhoud samen te stellen. Het zijn:

H. J. VETH, Overzicht van hetgeen, in het bijzonder door Nederland, gedaan is voor de kennis der Fauna van Nederlandsch Indië. Leiden, 1879.

M. J. SIRKS, Indisch Natuuronderzoek. Amsterdam, 1915. 
wilde men op een zóó uitgebreid veld van onderzoek het gestelde doel bereiken. Zeer zeker beteekende dit een belangrijke schrede op den goeden weg, de inluiding van een nieuw tijdperk, waarvan het beste mocht worden verwacht. Maar de afwisseling, waarvan hierboven sprake was, bleef de ontwikkelingslijn beheerschen en het stond geschreven, dat het nieuwe régime, hoezeer met groote geestkracht ingevoerd en toegepast, gedurende vele, vele jaren zou samenvallen met een ongunstige phase ervan. Gold dit het natuuronderzoek in het algemeen, het trof in bijzondere mate de biologie, het onderzoek der levende natuur, waarvan in den vervolge uitsluitend sprake zal zijn.

Wie nader kennis maakt met de geschiedenis van het biologisch onderzoek van Nederlandsch Indië van het begin der negentiende eeuw tot den huidigen tijd, vermag daarin alras twee tijdperken te onderscheiden, welker grens omstreeks het jaar 1880 is gelegen. Draagt het eerste tijdperk in menig opzicht de kenmerken eener periode van "Sturm und Drang”, heeft het tal van uitingen aan te wijzen van een goeden wil, die bijna even veelvuldig schipbreuk lijdt op gemis aan ervaring en onoordeelkundige verdeeling van den arbeid, doet het ons tal van phasen van ontmoediging en inzinking aanschouwen, die nu en dan op algeheele mislukking dreigen uit te loopen, het tweede geeft ons het beeld te zien van een meer evenwichtig nageslacht, dat zich plaatst op de schouders van zijn voorgangers en, zich zacht spiegelend in het leed van voorheen, zijn voordeel weet te doen met de lessen eener onfeilbare meesteresse.

De jaren vóór 1880 hebben, inzonderheid wat het dierkundig gedeelte van het onderzoek betreft, op een bijzonder geschikt oogenblik hun eersten geschiedschrijver gevonden. Men moge het uit anderen hoofde betreuren, dat de bekwame hand van Dr. H. J. VETH door een samenloop van omstandigheden was genoodzaakt de stift van Clio in plaats van ontleedmes en vergrootglas te hanteeren, voor onze kennis van hetgeen op het gebied van dit onderzoek aan de nieuwere periode voorafging, is zijn Academisch Proefschrift van onschatbare waarde, het juiste geschenk, gegeven op het juiste oogenblik, dat in zijn ongunstige auspiciën geen beteren kroniekschrijver had kunnen vinden dan den belangstellenden en deskundigen tijdgenoot.

Want rijk aan opwekkende perspectieven was dat oogenblik allerminst. Veeleer viel in des schrijvers jonge jaren een onmiskenbare inzinking waar te nemen van wat voorheen bij velen het karakter van geestdrift had gedragen, geestdrift voor het aan den dag brengen der onbeperkte rijkdommen, die Insulinde in haar flora en haar fauna verborgen hield, maar gansch niet onwillig aan den ernstigen natuuronderzoeker placht te openbaren.

Het hoogtepunt van die geestdrift lag ook in 1879 reeds ettelijke jaren achter den rug en zij, die erdoor waren bezield, hadden voor het meerendeel reeds lang tevoren een ontijdig einde onder de palmen gevonden. De geschiedenis der „Natuurkundige Commissie voor Nederlandsch Indië”, rampspoediger nagedachtenis, maakt het ons alleszins begrijpelijk, dat hier te lande, waar aard en omvang der gemaakte fouten goeddeels verborgen bleven, verslagenheid en moedeloosheid heerschten, instede van energie en hernieuwde ondernemingszucht; dat de hand, die men aan den ploeg had mogen verwachten, nog maar nauwelijks wees naar het veld, waar enkele oude voren van vroegere werkzaamheid spraken.

Maar dit alles behoort voor ons, menschen van 1922, tot een ver verleden, tot den ouden tijd. En zoo die tijd, juist op het tijdstip, waarop men hem als afgesloten mag beschouwen, ten slotte nog een Tacitus heeft gevonden, met wien hij mag worden gelukgewenscht, wij voor ons kunnen hem niet beter beschouwen dan als een harden leermeester, die ons op even welsprekende, als tragische wijze heeft aangetoond, hoe men het biologisch onderzoek van Indië niet ter hand moet nemen.

Deze korte, historische herinnering was noodig om de tegenstelling te accentueeren, die bestaat tusschen hetgeen vóór 1880 in het belang der natuurwetenschappelijke bestudeering van Nederlandsch Indië werd verricht en hetgeen ná dien tijd werd ondernomen. Voorheen goed bedoelde, maar veelal onberaden pogingen, die het onderzoekingsgebied in de koloniën beschouwden als een terrein, zonder meer vergelijkbaar met dat in de gematigde luchtstreken; verspilling van energie, soms met titanische onstuimigheid, vaker met begrijpelijk maar noodlottig ongeduld ten toon gespreid en zich daarom te pletter loopend tegen de ongastvrije schansen, door moeder Natuur daarginds tegen den onervarene opgericht; eerzucht aan de ééne, naijver aan de andere zijde, die in hun onderlingen strijd niet in de 
laatste plaats de bereikbare uitkomsten in de waagschaal stelden en ze daardoor menigmaal op een schamel erfdeel voor komende geslachten deden uitloopen.

Want maken eerste opzet en uitrusting der Natuurkundige Commissie niet den indruk, als waren ze meer bedoeld voor een gemoedelijke excursie naar de Veluwe, hoogstens naar het Beiersche hoogland, dan naar de tropische woestenij? Was niet het ontijdig einde van den genialen KuHL, zelfs van den meer bedachtzamen VAN HASSELT, met zekerheid te voorspellen door ieder, die, met onze huidige ervaring over het leven in de tropen gewapend, een blik slaat in de korte bladzijden van beider reisverhaal? En was niet ...... doch houden we deze vraag in de pen: de mortuis nil nisi bene.

En later? Zeer zeker niet op eenmaal de natuurwetenschappelijke heilstaat, maar allengs doordringend de overtuiging, dat het tropische onderzoekingsgebied behandeling eischt als veelzijdige eenheid, die in nagenoeg alle onderdeelen essentiëel verschilt van hetgeen men tevoren tot voorwerp van studie had gemaakt. Steviger post vattend de meening, dat slechts een bedachtzaam tempo, een welberaden "festina lente" zou kunnen voeren tot het doel, dat voorheen voor den "civium ardor" onbereikbaar was gebleken. Meer en meer bevestigd het inzicht, dat naast vele zaken, die uitsluitend ginds kunnen geschieden, tal van andere bestaan, die, hoèwel deelen van hetzelfde geheel, beter aan de oude centra van het Westen worden toevertrouwd en slechts in innige samenwerking daarmede tot hun gewenschte voltooiing kunnen worden gebracht.

Die overtuiging, die meening, dat inzicht, zij vormen den grondslag en de drie hoofdartikelen eener natuurwetenschappelijke belijdenis, die welhaast geen sectariërs meer op haar weg ontmoet; zij vinden hun onomstootbare bevestiging in de verblijdende uitkomsten, waarop het laatste veertigtal jaren met trots en voldoening kan wijzen.

Twee namen zijn, bij uitnemendheid, aan deze nieuwe bedeeling verbonden; twee grondleggers en bewerkers der biologische "renaissance” van Nèderlandsch Indië hebben aanspraak op de onverdeelde erkentelijkheid, zoo van den jongeren tijdgenoot, als van komende geslachten. Waar één van beiden, reeds een twaalftal jaren geleden, met droefheid in aller hart, onder den azuren hemel van Frankrijk's Zuidkust aan den schoot der aarde moest worden toevertrouwd, daar mogen wij het dubbel waardeeren, zijn vriend en geestverwant in deze wintermaand van $1922 \mathrm{nog}$ in ons midden te zien en hem een hulde te brengen, waarvan deze regelen niet meer dan een zwakke vertolking kunnen zijn. MELChIOR TREub en MAX WeBER, het zijn de beide namen, die onverbrekelijk en voor alle tijden zullen verbonden zijn aan het eerste bloeitijdperk van Indië's natuurwetenschappelijk onderzoek, de namen van hen, die de wegen hebben aangewezen, voor dat onderzoek te volgen, en op die wegen de voormannen zijn geweest.

Is men, onder de omstandigheden, waaronder heden ten dage het menschdom verkeert, wel eens ggeneigd zich af te vragen, of het inderdaad waar is, dat iedere tijd de mannen voortbrengt, die hij behoeft, voor het oogenblik, waarop TREUB en WEBER in de tachtiger jaren der vorige eeuw hun krachten in den dienst van Indië's onderzoek stelden, kan dienaangaande wel geen twijfel bestaan. Evenmin over het antwoord op die andere vraag, of in beider aanleg de factoren aanwezig waren voor die heilzame samenwerking in het belang der wetenschap, die voor het heden en de toekomst van fundamenteele beteekenis is gebleken. De dag moge nog verre zijn, waarop een toekomstig schrijver deze vraag zal kunnen beantwoorden met alle volledigheid, die thans den levende wellicht niet eenmaal aangenaam zou zijn, maar het zal den jongeren tijdgenoot, die het voorrecht had in beider nabijheid te staan, niet euvel worden geduid, wanneer hij wijst op het heugelijk samentreffen in tijd, aanleg en karakter, van twee naturen, die elkander ontmoetten op een terrein, dat hen nader dan iets anders aan het hart lag. TREuB, de eminente plantkundige, de grondlegger van nieuwe banen op menig terrein van botanisch onderzoek, de organisator van het wetenschappelijk onderzoek der koloniën, die tevens de uitkomsten ervan in dienst der praktijk wist te brengen, de onverwinlijke strijder voor elk nieuw denkbeeld, dat aan zijn vruchtbaar brein ontsproot, en bij dit alles de gelukkige bezitter eener even benijdenswaardige als onnavolgbare urbaniteit. Naast hem WEBER, in jaren zijn gelijke, op dierkundig gebied zijn evenknie, in praktischen blik zijn Hollandsche tegenhanger, in gelijke mate man van de wereld, van verfijnde vormen, van hooge geestesbeschaving. Kan het anders, of van zulk een samen- 
treffen mochten van den aanvang de vruchten worden verwacht, die het biologisch onderzoek van Insulinde thans heeft aan te wijzen en nog steeds in ruime hoeveelheden binnenhaalt?

Het mocht inderdaad een goede genius worden genoemd, die WEBER in het jaar 1888 voor een wetenschappelijke onderzoekingsreis naar Indië voerde. Met die reis werd een voorbeeld gevolgd, dat van buitenlandsche zijde reeds was gegeven door een reeks van natuuronderzoekers, aan wier spits wij WALLACE aantreffen. Op hare beurt heeft zij het ijs gebroken voor de talrijke Hollanders, die sedert dat oogenblik voor andere dan zuiver zakelijke doeleinden een tocht naar Indië op hun programma plaatsten. Was die van WEBER reeds daarom een heugelijke gebeurtenis, zij zou nóg in tweeërlei andere richtingen rijke vruchten dragen. De "Zoologische Ergebnisse" zijn dáár, om van ééne ervan te getuigen. Voor wie zich met de fauna van Indië heeft beziggehouden, vormen zij een rijke bron van de meest veelzijdige gegevens, waarop men, voor de daarin behandelde diergroepen, maar zelden tevergeefs een beroep doet. En voor wie zich erover moge verbazen, dat één natuuronderzoeker, vergezeld van een begaafde en eveneens vakkundige echtgenoote, in anderhalf jaar tijds zulk een rijkdom aan grootendeels nieuw materiaal kon bijeenbrengen, zij hier de bemoedigende verzekering neergeschreven, dat de toestanden heden ten dage nog even gunstig zijn voor den ondernemenden reiziger, die zich op de minder betreden paden van het groote eilandenrijk wil begeven.

De tweede richting, zooeven bedoeld, voert tot breeder terrein. WeBER's reis van de jaren 1888-1889 en de uitwerking van de resultaten ervan mogen worden beschouwd als het eerste werkstuk ten aanzien der Indische fauna, dat volkomen doelbewust en in rustig overleg werd ontworpen en met volledig succes tot in alle bijzonderheden werd uitgevoerd. Samen kunnen ze dienen - gelijk ze dat in de latere jaren reeds meermalen hebben gedaan - als een voorbeeld van de wijze, waarop ten opzichte der Indische natuurschatten moet worden te werk gegaan. En al zijn in het sedert verloopen tijdperk de toestanden gewijzigd en verbeterd, de leidende gedachte zal ook in de toekomst dezelfde moeten blijven. Hoofdzaak dier gedachte is een doelmatige verdeeling van den arbeid en een harmonische samenwerking der deelnemers, opdat elk stuk, zelfs het minst belangrijke, zoo volledig mogelijk tot zijn recht kome.

Vriendschappelijke wisseling van gedachten in de toenmaals nog zoo eenvoudige woning van den Directeur van 's Lands Plantentuin heeft ongetwijfeld het hare ertoe bijgedragen om dezen modus operandi voor beide hoofdgebieden der biologie tot klaarheid te doen komen en voor de toekomst tot richtsnoer te verheffen. Er werd een nieuw accoord geschapen, dat, wij zagen het daareven, weldra de proef van het experiment glansrijk zou doorstaan en eenige jaren later ten grondslag zou liggen aan een veel grootere onderneming, den kruistocht der „Siboga” door de Indische Zeeën.

Bij een zoo. veelzijdige en productieve activiteit als die van WEBER is het moeielijk, een „levenswerk" aan te wijzen, maar mocht een volgend geslacht zich voor die keuze zien geplaatst, dan komt het leiderschap der Siboga-expeditie en wat daaraan verbonden is geweest, ongetwijfeld een der beste kansen toe. Wie deze feestuitgave ter hand neemt, kan ongetwijfeld elke verdere uitweiding ontberen; hem zijn voldoende bekend omvang en beteekenis van het monument, tastbaar onder meer in een lange reeks van statige deelen, waaraan de naam "Siboga" is verbonden, een monument, dat zeer zeker in de eerste plaats strekt tot eere van Nederlandsche wetenschap, geestkracht en ondernemingszucht, maar deze alle voor tijdgenoot en nageslacht tot uitdrukking doet komen in den persoon van hem, die het ontwierp en voltooide. Wat echter ook hier onder de aandacht zij gebracht, is de volkomen juiste en doeltreffende verdeeling van den arbeid onder alle personen en lichamen, die tot het welslagen dezer grootsche onderneming moesten samenwerken, in Indië en in Europa, is de talentvolle wijze, waarop die samenwerking tot het einde is geleid.

Daar is - wij gaan het kleinere voorbij - nog een derde zaak te noemen, aangelegenheid van den eersten rang voor het natuuronderzoek van Indië, die de deugdelijkheid van het nieuwe accoord in het volle licht stelt. Verlangen naar archiefstukken is een zeldzaam verschijnsel, maar hoe gaarne zouden wij voor een oogenblik beschikken ${ }^{\varsigma}$ over den brief, in het begin van 1909 door WEBER tot TREUB gericht, waarin het denkbeeld wordt ter sprake gebracht, een aanvang te maken met een „Fauna van Nederlandsch Indië”. Allerminst een vaag denkbeeld alléén, doch een volledig plan de campagne: de werkwijze uiteengezet, een begrooting van kosten bijgevoegd en daarbij de bereidverklaring, zelf, met de hulp van een jongeren medewerker, de omvangrijke groep der Visschen ter hand te nemen. 
Kan het. verwondering baren, dat te Buitenzorg in de aldus toegereikte hand onmiddellijk werd toegeslagen, dat reeds de Indische staatsbegrooting voor 1910 in staat stelde een aanvang te maken met het groote werk, waaraan - wij moeten helaas uit het geheugen aanhalen - „ik gaarne bereid ben, mijn levensavond te wijden".

Van "The Fishes of the Indo-Australian Archipelago", by MAX WEBER and L. F. DE BEAUforT, is juist het Vierde Deel verschenen en daarmede is ongeveer de helft voltooid van een werk, dat mag worden beschouwd als waardige tegenhanger en tegelijk welkome aanvulling van hetgeen van Engelsche zijde voor meer Westelijk gelegen terreinen werd verricht. Daarnaast verschenen, als onderdeel van dezelfde serie faunistische werken over Nederlandsch Indië, twee. Deelen over de Reptilia, bewerkt door Mej. Dr. NeLly DE Rooy, terwijl voorts een manuscript van den Leidschen Hoogleeraar, Dr. P. N. van KAMPEN, gereed ligt voor publicatie, waarin de Amphibia worden behandeld en ten slotte onderhandelingen gaande zijn over de bewerking der Vogels en der Zoogdieren. Altemaal verblijdende feiten, niet alleen voor wie zich in het algemeen bewust is van de verplichtingen, die de uitgestrektheid van het Nederlandsche gebied ook op wetenschappelijk terrein medebrengt, maar ook en vooral voor den vakgenoot, die daarginds op dierkundig gebied werkzaam is en niet meer, gelijk voorheen, van elk middel ter oriënteering is verstoken.

Waar twee leidende figuren op biologisch gebied aldus in vruchtbare samenwerking zijn voorgegaan, zullen jongere tijdgenooten en volgende generaties dat voetspoor hebben te volgen en ervoor hebben te waken, dat de ontwikkelingslijn van Indië's natuuronderzoek niet wederom in een dal verloope.

Daar was hierboven sprake van een nieuwe, natuurwetenschappelijke belijdenis en een drietal hoofdartikelen daarvan; het kan wellicht zijn nut hebben, nog een oogenblik daarbij te verwijlen.

Het valt niet te ontkennen, dat de tropische natuur in haar wezen iets anders is dan die der gematigde luchtstreken; men bespeurt niet alleen een kwantitatief verschil in rijkdom aan plant- en diervormen, maar de geest, die uit het geheel dier vormen tot den natuuronderzoeker spreekt, is een andere dan die onder den Hollandschen hemel. Wie zich voor de eerste maal bevindt in het ongerepte tropische woud, het palladium der tropische natuur, vermag zich aan dien indruk niet te onttrekken. Hij gevoelt zich als een ongewenschte vreemdeling, erger nog, als een onbescheiden indringer. Hij gevoelt zich als zoodanig beschouwd door de machtige coenobiose der vormentijke flora en fauna, die, véél meer dan in de gematigde luchtstreken, één samenhangend en als 't ware tegen hem samenspannend geheel uitmaakt. Gevaren van allerlei aard, veelal zeer zeker slechts kleinere, maar ook enkele grootere, omringen hem. Zij treffen al spoedig in de brandharen van deze, in de grijpende doornstekels van gene plant, in de steken van tallooze Diptera, in de beet van een kleinen Bloedzuiger, die tusschen zijn kleeren weet door te dringen. Maar meer nog dan door dit lijdelijk verzet en deze kleine agressies, spreekt de tropische natuur tot hem door haar stille, hooghartige majesteit, die geen bewondering vraagt en van geen toenadering wil weten.

Die machtige coenobiose ontleent voor een overwegend groot gedeelte haar aanzien aan een klimaat, dat aan een voortdurende, onafgebroken ontwikkeling geen hinderpaal als winterkoude in den weg legt, waardoor de banden, in lente en zomer gelegd, telkenjare aan het einde der vegetatieperiode weer goeddeels verloren gaan. Hier geen jaarlijksche scheiding, maar een blijvende vereeniging, een eeuwigdurende alliantie, waaraan de verbondenen hun gezamenlijke kracht ontleenen. Die verbondenen elk voor zich, ze bovendien in hun onderlingen samenhang, hun vaak gecompliceerde verhoudingen te leeren kennen, stelt aan het natuuronderzoek in de tropen geheel andere en oneindig veel hoogere eischen dan elders, maakt het tot een zaak, die afzonderlijke studie, afzonderlijke opleiding, ook zelfopleiding, ter plaatse vereischt.

Staan wij hier voor een feit, dat in vroeger jaren maar al te vaak over het hoofd werd gezien en tot tal. van teleurstellingen leidde, tegen het tweede artikel is voorheen niet.minder veelvuldig gezondigd. „Festina lente”, zoo luidde reeds daarstraks het parool, dat voor den natuuronderzoeker in de tropen bij uitnemendheid is aangewezen, het wachtwoord ook, dat TREUB steeds ieder nieuw aangekomen medewerker placht toe te roepen. Zelfs den zeer tijdelijken werker, die het dikwijls noode opvolgde, maar zelden ongestraft in den wind sloeg. Het vindt zijn oorzaak in vele dingen, in de 
eerste plaats in het persoonlijk welzijn van den nieuweling, wien het niet geraden is, met kracht van wal te steken, vóórdat hij de metamorphose tot tropenbewoner heeft doorgemaakt. Accomodatie aan de nieuwe omstandigheden van klimaat, levenswijze, omgeving van land en volk, zij moge eenigen, soms zelfs geruimen tijd in beslag nemen, maar zij is een uitgave à fond perdu, waarvan menige droevige ervaring uit den ouden tijd de volkomen noodzakelijkheid heeft aangetoond.

Naast haar is bedachtzaamheid in den arbeid zelf geboden. In gelijke mate als de tropische natuur een studie-object is van ongekend ingewikkelde samenstelling, zijn de wegen vele, die bij het onderzoek op een dwaalspoor voeren. In den doolhof van belangwekkende verschijnselen den juisten weg te vinden, is meestal slechts weggelegd voor wie langzaam voorwaarts gaat en zijn, overigens begrijpelijk, ongeduld weet te bedwingen. Zelfs het ongeduld van anderen - wie medewerkers in de tropen heeft, zij dit indachtig - mag hier geen gewicht in de schaal leggen.

Eindelijk het derde, verreweg het belangrijkste artikel, waar over samenwerking tusschen Nederland en Indië wordt gesproken.

De geestesgesteldheid, waarop in den aanhef dezer bladzijden werd gezinspeeld als een der oorzaken van minder goede samenwerking tusschen Nederland en Indië, droeg ten allen tijde het karakter eener fatale drieëenheid, waarvan eerzucht, bemoeizucht en naijver de componenten waren. Een verdere ontleding ervan, op deze plaats, ligt echter evenmin in de bedoeling als het in herinnering brengen van droevige feiten, die aan haar, en uitsluitend aan háár alleen, zijn toe te schrijven geweest. Volstaan wij met haar te gedenken als een geleden kwaad, dat nu en dan nog het hoofd tracht op te steken, maar overigens behoort tot een verleden, waarmede het huidige geslacht heeft afgerekend. Dank zij leiding en voorbeeld, door WEBER en TREUB gegeven, wordt het heden door andere, betere factoren beheerscht, hebben onderling vertrouwen, en een juiste verdeeling van den arbeid de vrijgekomen plaatsen bezet.

Onderling vertrouwen; onze eeuw met haar snelle, gemakkelijke, veelvuldige verplaatsingen, haar persoonlijk contact tusschen allen, die tot samenwerking geroepen zijn, haar specialiseering op elk gebied van wetenschap roept zulk een vertrouwen ongetwijfeld eerder in het leven dan een vroeger tijdperk vermocht te doen, waarin van dit alles nog geen sprake was. Daar was slechts een krachtig voorgaan noodig, een stoot in de goede richting, om tot mondig te doen verklaren wie voorheen maar al te gauw voor onbevoegd werd gehouden. De raadgeving uit Indië, de aanwijzing uit Holland, of het omgekeerde, vroeger niet zelden met gebaar van ontstemming terzijde gelegd, worden heden als regel niet meer tot dooveman's deur gericht. Er is een nieuwe atmosfeer geschapen, waarin het moderne onderzoek der Indische natuur met graagte en ruimte ademt en waarvoor het den scheppers grooten en oprechten dank is verschuldigd.

Een juiste verdeeling der werkzaamheden; een aanzienlijk deel ervan kan uit den aard der zaak slechts ter plaatse, in Indië, geschieden, maar er is een ander deel, dat beter aan de Westersche centra wordt toevertrouwd. Zich tot het eerste te beperken, het tweede aan bekwame vakgenooten over te laten, moet ook hier het kenmerk van den meester zijn. Aldus hebben beide voorgangers het ingezien en hun inzicht is allengs gemeen goed geworden. Het heeft, om een enkel voorbeeld te noemen, geen zin, dat de bioloog daarginds, tenzij op eigen, speciaal gebied, zijn dagen besteedt aan tijdroovende determinaties en beschrijvingen, wanneer hetzelfde werk in een ander centrum met dubbele vlugheid en drievoudige zekerheid kan geschieden. En zoo het hem aan het hart mocht gaan, zijn naam niet als auteur aan het nieuwe te kunnen verbinden, hij krijgt daarvoor een goede kans in ruil, bij den doop van soort of van geslacht aan de vergetelheid te worden ontrukt. Aan den anderen kant werkt het remmend op den vlotten gang van zaken, wanneer uit het Westen, meer dan onvermijdelijk is, door aanwijzing; of opdracht wordt getracht invloed uit te oefenen op hetgeen in het verre Oosten geschiedt; men drage hier de overtuiging met zich, dat het werk daarginds aan bevoegde handen is toevertrouwd, volkomen in staat om bij veranderend getij de bakens te verzetten en bij elken wind op eigen kompas te zeilen.

Algemeene regels, voorschriften, die in elk voorkomend geval kunnen voorzien, zijn hier niet te geven; TREUB noch WEBER heeft ooit dâarnaar gestreefd. Maar beider voorbeeld en de ruime opvattingen, die aan elk hunner handelingen tot grondslag hebben gediend, mogen voor lange toekomst een veilig en betrouwbaar richtsnoer blijven. 